УАK (UDC) 141.319 .8

DOI: 10.26565/2226-0994-2019-60-1

Nataliia Zahurska

\title{
SEXUALITY IN A CONTEXT OF SPECULATIVE POSTHUMANISM: HUMAN-POSTHUMAN RUPTURES AND DISCONNECTIONS
}

In this article human-posthuman ruptures and disconnections both in comprehension and in practices, as well as the possibility of epistemological contingency contemporaneously are investigated. This means that an epistemological ruptures and an ontological disconnections of sexuality both differ from one another, and also join together. Since ancient times both sensitive and sensible practices of sexuality were considered the best mode to concern to sexual care of self. It has shown that, in relation to sexuality, a correlation of epistemological discontinuity and continuity is possible. Sexuality, which is actualized with the help of both natural, vital and death, annihilative drives, fits into the context of onticology as a posthuman ontology. Being connected with the thermodynamics of infinitesimal vital parts, anonymous strange strangers, singularities, it turns out to be especially awesome. Such a mode of sexuality is not necessarily reproductive; rather, it unfolds in the fluid space of non-presence and at the same time determines this space. It emphasizes that that the cos mo-illogical becoming of posthuman leads to negentropy or extropy as vitality. Following this position, the foucaultian conception of the care of self mirrors lacanian graphs of sexuation in a context of object-oriented ontologies in comparison with philosophies of presence. It is recognized that this is the sexuality of the productive disconnection and the pleasure cosmic dissolution. This article concludes by illustrating that the mode of sexuality of Speculative Posthumanism is contingent with the Libidinal Materialism or Vital Posthumanism in a context in which the sexuality of Wide Human Descendants (WHDs) is thought to be oriented to that which is pleasure and is differentiated.

Keywords: epistemological breaks, human-posthuman disconnection, Wide Human Descendants (WHDs), sexuality, pleasure.

In contemporary philosophical anthropology, the problem of the difference and even differentiation between the human and the posthuman is acute. This acuteness is caused by the relation of this problem to discussions about epistemological ruptures. In the context of Speculative Posthumanism, these ruptures appear as a human-posthuman disconnection. In this article, we consider the sexual aspects of the problem of ruptures and disconnections by focusing primarily on the work of M. Foucault and D. Roden as well as that of other researchers.

In this article M. Foucault's method of problematization is used, which he first mentioned in The History of Sexuality (Vol. 3: The Care of the Self) and which implies that one consider not so much the ideology, the behavior or the representation, but thinking about it and its conditions foremost. The complexity of the application of this method lies in the fact that the thinking human being, who carries out discursive and non-discursive sexual practices, is problematized. However, it is this method that allows one to search for the nuances of difference in posthuman sexuality.

In M. Foucault's opinion, a series of epistemological ruptures, disconnections and gaps occurred between words and things. These epistemological ruptures or disconnections also influenced the comprehension and practice of sexuality, as well as how the subject of sexuality was first viewed. Thus, it can be traced back to the «history of the experience of sexuality, where experience is understood as the correlation between fields of knowledge, types of normativity, and forms of subjectivity in a particular culture» [Foucault, 1985, p. 4]. For example, M. Foucault stresses that, although refinement of constituting oneself as the ethical and economical subject appeal to sexuality and pleasure, the artification of sexual living includes demands of sexual austerity. "The sexual act appears to have been regarded for a very long time as dangerous, difficult to master, and costly; a precise calculation of its acceptable practice and its inclusion in

(C) Zahurska N. V., 2019.

$(\mathrm{cc}) \mathrm{EY}$ This is an open-access article distributed under the terms of the Creative Commons Attribution License 4.0. 
a careful regimen had been required for quite some time» [Foucault, 1986, p. 237]. But although the requirement of sexual rigor is characteristic of both the ancient and the Christian approaches to pleasure practices, an obvious rupture occurred between them. «But one should not be misled by the analogy. Those moral systems will define other modalities of the relation to self: a characterization of the ethical substance based on finitude» [Foucault, 1986, p. 239]. Perhaps this is one of the reasons that, in the context of Speculative Realism, the problematization of sexuality is not realized: after the finitude of the human, off-season sexuality that does not have reproductive value turns out to be unnatural, while D. Roden emphasizes the urgency of naturalization, up to the naturalization of deconstruction. And this can be accompanied by the re-animation of the ancient practical subject of sexuality.

On the other hand, Cartesian and Kantian subjects appear as mechanisms of repression. M. Foucault problematizes two more epistemological ruptures having to do with sexuality. The first of them, which appeared in the seventeenth century, surmised that except for the reproductive practice of adult married couples the manifold of sexual practice was considered to be prohibited. Both the body and the language attempted to conceal and suppress sexuality as much as possible and that was the main threat to sexual discursiveness.

The next episteme, which can be conditionally designated as human, is characterized by a sexual discourse of allegories and hints in the field of everyday life and clinical codification in the sphere of comprehension of sexuality. Its image changed from ars erotica to scientia sexualis and the medicalization of sexuality. M. Foucault attracted attention by claiming that it «was really less a rupture than an inflexion of the curve» [Foucault, 1978, p. 115] because of the loosening of repressions and taboos and the reduction of sexuality such as prenuptial, perverse, childish, etc.

Currently, a transition to a posthuman episteme is occurring, which, on the one hand, accumulates the features of the previous ones, and, on the other hand, can be considered as fundamentally different, which gives D. Roden the opportunity to affirm the existence of a disconnection between the human and the nonhuman. If a fold of subjectivity is accomplished by finite forces - Labor, Language and Life itself - their intertwining generates a whole range of anthropological nuances, such as literary work, libidinal economics, text erotica and many other projective aspects. M. Foucault precisely reflected not only on the ultimate and flawed projectivity of finite forces, but also on the derivation and, at the same time, the foundation of this projectivity. After the collapse of the human project, the place of Life, Labor and Language is occupied by the pure extensions of Death, Desire and Law as G. Bataille emphasizes. When presentation is suspended in terms of opening to closing, finitude becomes an intersection of the lines of death without pleasure, desire without an object, and language without the signified. In this eventfulness not only a sexual epistemology, but also an erotic ontology, which contains a large part of mortido as well as libido, is explicated. Additionally, according to T. Morton, such an ontology may be designated as a weird ontology or, according to Levi R. Bryant, an onticology. An onticology implies that an intersection of lines occurs in singularity.

In Sex and The Singularity, A. Laitman affirms that after the singularity sex will become awesome, the degree of pleasure will increase exponentially and it will become extremely subtle our sex life will become simply glorious. «As long as we cannot replace our own bodies, we may just as well start our journey towards limitless (and limitlessly pleasurable) existence by replacing the body of the other, or more precisely by redirecting our affection to a different kind of body, one that is far less messy and, perhaps more importantly, remains forever unaware of our own body's many imperfections» [Hauskeller, 2014, p. 11]. According to M. Heim, this will mean the beginning of sexual relations between the self and space as such [Heim, 1991, pp. 83-84]. And this experience will be inherently philosophical. It will first and foremost be the sexualized philosophy of space as in W. Gibson's Count Zero: «Bobby remembered being thirteen and in love with Brandi, the one with the blue rubber pants. Now he valued the projections mainly for the illusion of space they could provide in the makeshift bedroom» [Gibson, 1986]. W. Gibson considers that the singularity, decrementing the count to zero happens on receiving an interruption or disconnection. 
This opinion may be juxtaposed to Libidinal Materialism without telos or intention, which N. Land claimed resulted from the annihilative potential of libidinal matter with specific chaotic thermodynamics and the pre-ontological dimension of energy. Unconditional, non-teleological desire creates onticological effects of composition of chaos as an immense ocean of annihilation. Echoing F. Nietzsche, N. Land stressed that the libidinal reformulation of being is composition: «the effect of "being" is derivative from process» [Land, 1992, p. 44]. Thus, he returns from an orientation on becoming to an orientation on being, which is why Libidinal Materialism paradoxically or parallaxically appears as Transcendental Materialism. This also means a return from a lacanian comprehension of desire as a lack to a Freudian comprehension of desire as a dissipative energetic flow. This, in addition, makes an effect on humanity as a whole: «the humanizing project has the form of an unsustainable law. Despite the fortifications of prohibition, the impossible corrosion of humanity in eroticism; the eruption of irreducible excess, which is the base unity of sexuality and death. Eroticism gnaws us as the inevitable triumph of evil (utter loss)» [Land, 1992, p. xix]. Considering N. Land's explanation, S. C. Hickman pushes the possibilities of Libidinal Materialism to the limit: «Libidinal Materialism is so much more than this bare minimum statement of principles, but this is a base line from which its interactions begin» [Hickman, 2012a]. But the thermodynamic of Libidinal Materialism can be designated not so much as an entropy, as much as a negentropy or extropy. It can be an infinitesimal vitality, i. e. a vitality of a virus like a vitality of nihilistic or annihilative sexuality, the sexuality of virulent potential or virulent potency. This annihilative potency is cos mo-illogical and adducts to dissolution in a cosmic flux, which may cause us to feel ill, but, according to P. MacCormack, this illness of becoming posthuman or ahuman is an excess of human. She borrows the notion of the cosmogenic mode of interaction from M. Serres and affirms that «along with the perhaps seemingly nihilistic sounding, but utterly affirmative, the vindication of human extinction and the care of immanent and living life of posthuman sexuality performs over an immortalising obsession with lives yet to come into being; posthuman sexualities have diversified toward monsters, spiritualities (without theism) and on a grander scale, a cosmic understanding of connectivity that could be described as cosmogenic» [MacCormack, 2018, p. 41]. In a certain sense, the ahuman model of sexuality describes the cosmogenic pleasure and jouissance of anonymous infinitesimal.

Thus, completely anonymous application of Pure, in which chats disappear after an hour of communication, which clearly hint that it is time to move on to body communication, directly proposes to pretend like people are strangers. That is, everyone is a strange community, a strange stranger, according T. Morton. Moreover, proceeding from the speculative realism that D. Roden describes such a situation as «a minimal, non-transcendental and nonanthropocentric humanism and will help up put bones on its realist commitments» [Roden, 2015, p. 36]. Within the context of speculative realism there exists the belief that posthuman radically differs from human. This precisely means that radical differentiation is not different because even deconstruction is tainted with Kantianism. In essence, this radical break between humans and posthumans or even inhumans as WHDs such a posthumanism is conceptualized as Vital Posthumanism.

From a philosophical viewpoint, this means that there is a preference for techné in comparison with anamnesis, for example, in mnemotechnics and appellation rather than for Aristotle to Plato. But it is a vitalizing techné as in The Internet of Things or even The Internet of Objects. «Whereas we once were locked into a brain / environmental system of survival and sex within a natural world, we are more and more beginning to disconnect from this ancient system and re-ontologize ourselves and environment as an artificial world» [Hickman, 2017]. S. C. Hickman stresses that this happens in reverse to ancient notions of techné, which is comprehended as a tool or prosthesis foremost of the human mind to independency and autonomy direction «from Plato to Derrida. We are being re-written, re-programmed, and re-engineered» [Hickman, 2017].

In this regard, D. Roden focuses on the importance of body experiences, including the body experiences of other beings. A capacity to feel other beings' pain and pleasure is 
especially important to sexual body experiences. But D. Roden implicitly takes into account the Foucaultian criticism of reproductive sexuality, referring to D. Chalmers' well-known statement if we have better sex it does not follow that our babies will be geniuses. This clearly disconnectes human sexuality, which is largely based on the instinct of the continuation of the genus, from the posthuman sexuality of desire and especially pleasure: «Speculative Posthumanism is a weaker claim than SH and thus more plausible» [Roden, 2012, p. 284]. As for reproduction, disjunctive tactics in relation to sexuality develops. Additionally, this is not the improvement or the augmentation of human capacities in a transhumanism way. Even human transgenic and uploading issues problematize first of all mind-cloning. It has a capacity to have and express propositional attitudes of WHDs synthetic life-forms.

D. Roden expands on this thought in his Posthuman Life: Philosophy at the Edge of the Human: «if these alternative modes of genetic transmission became routinely used alongside regular sex, the homeostatic role of reproductive barriers would be significantly reduced» [Roden, 2015, p. 115]. Such an approach is no longer regarded as bizarre or ridiculous, although it is not worth denying that is has these qualities, which are simply productive, but are also more and more actualized in all its powerfulness. "The disconnection relation is thus multiply realizable by entities with, conceivably, very disparate natures. But since all these would be powerful enough to become "feral", the majority of these would be hot cores of influence of a kind humans have not encountered before» [Roden, 2015, p. 167].

These capacities include possibilities not only to speculate, but also to create non-symbolic and even non-linguistic spaces with a marked sexual potential: «the differences between humans and posthumans might be so great as to render accounting impossible or problematic in the cases that matter» [Roden, 2015, p. 282]. Thus, metaphysically it means not essentialism, but constructivism with disconnection not only in the sense of human-posthuman disconnection, but also in the disconnection between beings in theirs differentiations and even disconnections, their losses and the strifes they experience that are expressed in epistemological ruptures. But this constructivist assemblage is somewhat more natural and vital.

Critiques of $\mathrm{OOO}$ as A. Lillywhite stress the dangers of biologism and while J. Rosenberg emphasizes the dangers of the primitivism of moleculazing sexuality, which also impugn shizoanalitical sexuality conception. But such researchers as N. Land and especially S. C. Hickman in his The Poem of the Sea: Speculative Materialism and Realism follow F. Nietzsche, G. Bataille and particularly A. Badiou with his proclamation of the need to break away from Idealism in philosophy and to turn to re-animation as an infinitesimal subject, which doesn't fit into any of the concepts of the subject and is more like an object in OOO understanding. Sexuality of this subject also doesn't fit in any conception, but it may be carols in Speculative Realism as a contingental Dionysian chthonian fluidity and slimy, after burning the «Apollonian formalism of science, we discover the terminal phase of postmodern culture in an electrical gaze between masks that forms a new object: an erotic, molten dance of sensual objects and thought» [Hickman, 2012a]. But unlike N. Land, S. C. Hickman notes that the rupture from Idealism means that both materialism and realism play a productive vie.

If, according to K. Hayles and N. Badmingon, we already became posthuman and WHDs are we, and we are WHDs, then sexual anticipation became sexual participation and imagination occupies an appropriate position among other registers of the psychic. Developing a thought from The Democracy of Objects, Levi R. Bryant (aka larvalsubjects) pays attention to the possibility of comprehending Lacan's graphs of sexuation in an object-oriented ontologies context. Thus, he stresses that not only a woman, but the world doesn't exist. If the masculine side of the graph is associated with a phallic function and presence, then the feminine side is associated with difference and non-presence:

«Philosophies of Presence: All are submitted to withdrawal with one exception. There is one that is not.

Object-Oriented Ontologies: Not all are submitted to withdrawal. But there is no exception. There is none which is not is not submitted to withdrawal» [larvalsubject, 2010]. 
In the blog a variety of beings, including animals, appear as WHDs. Some are fabulated beings and their sexuality may seem bizarre. For example, the grievance of a user with a snugglebug nick on is babbling away about the sex of angel to be. Thus, this warns about disconnections up to exception between different sorts of posthuman beings. But the depiction of intercourse with a resuscitated wife from Ben Marcus's The Age of Wire and String appears as especially expressive and indicates the withdrawal and reconciled non-presence.

In conclusion, it should be noted that, in the context of Speculative Posthumanism, much more attention is paid to sexuality and eroticism in comparison with Speculative Realism and OOO. This is primarily due to a comparison of the conceptualization of contingency with Libidinal Materialism and the underscoring of excessive possibilities of the contingency. It is shown that epistemological discontinuities and human-posthuman discrepancy in relation to sexuality are manifested in a rupture from Idealism, a rupture from reproductive sexuality and sexuality of desire and pleasure, and also in the fundamentally different posthuman sexuality of WHDs.

\section{REFERENCES}

Foucault, M. (1978). The History of Sexuality (Vol. 1: An Introduction). N.-Y.: Pantheon.

Foucault, M. (1985). The History of Sexuality (Vol. 2: The Use of Pleasure). N.-Y.: Pantheon.

Foucault, M. (1986). The History of Sexuality (Vol. 3: The Care of the Self). N.-Y.: Pantheon.

Gibson, W. (1986). Count Zero. London: Victor Gollancz Ltd. Retrieved from http://project.cyberpunk.ru/lib/count_zero.

Hauskeller, M. (2014). Sex and Posthuman Condition. N.-Y.: Palgrave Macmillan.

Heim, M. (1991). The Metaphysics of Virtual Reality. N.-Y.: Oxford University Press.

Hickman, S. C. (2012a). Libidinal Materialism: Nick Land's Philosophy of Desire. Retrieved from https://socialecologies.wordpress.com/2012/11/04/libidinal-materialism-a-philosophyof-desire.

Hickman, S. C. (2012b). The Poem of the Sea: Speculative Materialism and Realism. Retrieved from https:// socialecologies.wordpress.com/2012/10/09/the-poem-of-the-sea-speculativematerialism-and-realism.

Hickman, S. C. (2017). The Posthuman Disconnection. Retrieved from https://socialecologies.wordpr ess.com/2017/07/27/the-posthuman-disconnection.

Land, N. (1992). The Thirst for Annibilation: Georges Bataille and Virulent Nibilism (An Essay in Atheistic Religion). L.: Routledge.

Larvalsubjects. (2010, June 28). Lacan's Graphs of Sexuation and OOO. Retrieved from https://larvalsubjects.wordpress.com/2010/06/28/lacans-graphs-of-sexuation-and-ooo.

MacCormack, P. (2018). Posthuman Sexuality: From Ahumanity to Cosmogenic Desire. In C. Åsberg \& R. Braidotti (Eds.), A Feminist Companion to the Posthumanities (pp. 35-44). Dordrecht; Heidelberg; L.; N.-Y.: Springer.

Sex and The Singularity. (2009, October 9). Retrieved from http://hplusmagazine.com/2009/10/0 $9 /$ sex-and-singularity.

Roden, D. (2015). Posthuman Life: Philosophy at the Edge of the Human. N.-Y., L.: Routledge.

Roden, D. (2012). The Disconnection Thesis. In A. Eden, J. Søraker, J. Moor \& E. Steinhart (Eds.), The Singularity Hypothesis: A Scientific and Philosophical Assessment (pp. 281-300). Berlin: Springer.

\section{Zahurska Nataliia V.}

D.Sc. in Philosophy, Professor of the Department of Theoretical and Practical Philosophy named after Professor J. B. Schad

V. N. Karazin Kharkiv National University

6, Svobody sqr., 61022, Kharkiv, Ukraine

E-mail: zagurskaya@karazin.ua

ORCID: http://orcid.org/0000-0001-5142-8064

Article arrived: 22.04.2019

Accepted: 27.05.2019 


\section{СЕКСУАЛЬНІСТЬ У КОНТЕКСТІ СПЕКУЛЯТИВНОГО ПОСТГУМАНІЗМУ: АЮАСЬКО-ПОСТАЮАСЬКІ РОЗРИВИ ТА РОЗ’ЄАНАННЯ}

\section{Загурська Наталія Віталіївна}

Аоктор філософських наук, професор кафелри теоретичної і практичної філософії імені професора Й. Б. ШаАа

Харківський національний університет імені В. Н. Каразіна

м. Свободи, 6, Харків, 61022

E-mail: zagurskaya@karazin.ua

ORCID: http://orcid.org/0000-0001-5142-8064

У цій статті досліАжуються мюдсько-постлюАські розриви та роз’єАнання як в осмисленні, так і в практиках, а також можливість епістемологічної контингентності. Це означає, що епістемологічні розриви та онтологічні роз’єАнання сексуальності як віАрізняються одні віА одних, так і об’єАнуються. 3 античних часів як чуттєві, так і раціональні практики сексуальності розглядалися як найкращий модус ставлення до сексуальної турботи про себе. Це показує, що стосовно сексуальності можливе співвідношення епістемологічної перервності та неперервності. Сексуальність, що реалізується за допомогою як природних, вітальних, так і смертельних, анігіляційних Арайвів, вписується в контекст онтикології як постАюдської онтології. Будучи пов’язаним $з$ термодинамікою нескінченно малих вітальних частин, анонімних «Аивних Аиваків», сингулярностей, це виявцяється особливо вражаючим. Такий модус сексуальності не обов'язково є репродуктивним: він радше розгортається в ріАкому просторі не-присутності та водночас Аетермінує цей простір. Це піАкреслює, що «кос мо-іАлогічне» становлення постАюАського призводить до негентропіі або екстропії як вітальності. ЗгіАно 3 цією позицією, фукіанська концепція турботи про себе вілцзеркалює маканіанські графи сексуації в контексті об’єктно-орієнтованих онтологій у порівнянні з філософіями присутності. Визначено, що це сексуальність продуктивного роз'єАнання та космічного розчинення, що приносить задоволення. Стаття завершується висвітленням того, що модус сексуальності спекулятивного постгуманізму контингентний Аібілінальному матеріалізму або вітальному постгуманізму, в контексті якого сексуальність Обширу Аюдських Нащадків (ОАНв) вважається орієнтованою на те, що задовольняє іє Аиференційованим.

Ключові слова: епістемологічні розриви, АюАсько-постАюАське віАкАючення, Обшир Аюдських Нащадків (ОАНв), сексуальність, задоволення.

\section{СЕКСУААЬНОСТЬ В КОНТЕКСТЕ СПЕКУАЯТИВНОГО ПОСТГУМАНИЗМА: ЧЕАОВЕЧЕСКО-ПОСТЧЕАОВЕЧЕСКИЕ РАЗРЫВЫ И РАЗЪЕАИНЕНИЯ}

\section{Загурская Наталья Витальевна}

Аоктор философских наук, профессор кафедры теоретической и практической философии имени профессора И. Б. Шада

Харьковський национальный университет имени В. Н. Каразина

пл. Свободы, 6, Харьков, 61022

E-mail: zagurskaya@karazin.ua

ORCID: http://orcid.org/0000-0001-5142-8064

В этой статье исследуются человеческие и постчеловеческие разрывы и разъединения как в понимании, так и в практиках, а также возможность эпистемологической контингентности. Это значит, что эпистемологические разрывы и онтологические разъединения сексуальности как отличаются Аруг от Аруга, так и объединяются. С античных времен как чувственные, так и рациональные практики сексуальности считались мучшим модусом заботы о себе. Это показывает, что в отношении сексуальности возможна взаимосвязь эпистемологической прерывистости и непрерывности. Сексуальность, которая реализуется с помощью естественных, витальных и 
смертоносных Арайвов, вписывается в контекст онтикологии как постчеловеческой онтологии. Будучи связанным с термодинамикой бесконечно малых витальных частиц, анонимных «странных странников», сингулярностей, это оказывается особенно поразительным. Такой модус сексуальности не обязательно является репродуктивным: скорее он разворачивается в жиАком пространстве отсутствия и в то же время определяет это пространство. Подчеркивается, что «кос мо-илмогическое» становление постчеловека приводит к негэнтропии или экстропии как витальности. Согласно этой позиции, фукианская концепция заботы о себе отражает макановские графы сексуации в контексте объектно-ориентированных онтологий по сравнению с философиями присутствия. Определено, что это сексуальность проАуктивного разъединения и приносящего удовольствие космического распаАа. Эта статья завершается илАюстрацией того, что моАус сексуальности спекулятивного постгуманизма контингентен АибиАинальному материализму или витальному посттуманизму, в контексте которого считается, что сексуальность Размаха Человеческих Потомков (РЧПв) ориентирована на то, что уАовлетворяет и является Аифференцированным.

Ключевые слова: эпистемологические разрывы, человеческо-постчеловеческое разъединение, размах человеческих потомков (РЧПв), сексуальность, удОвольствие.

Статья поступика в редакцию: 22.04.2019

Утверждена к печати: 27.05.2019 